\title{
Haemophilia-A-related haematoma: management in resource constraint settings
}

\author{
Deba Prasad Dhibar, Kamal Kant Sahu, Prateek Deo, Subhash Varma
}

Department of Internal Medicine, Post Graduate Institute of Medical Education and Research, Chandigarh, India

\section{Correspondence to} Dr Deba Prasad Dhibar, drdeba_prasad@yahoo.co.in

Accepted 26 July 2016

\section{- -}

To cite: Dhibar DP, Sahu KK, Deo P, et al. BMJ Case Rep Published online: [please include Day Month Year] doi:10.1136/bcr-2016215933

\section{DESCRIPTION}

Haemophilia is a X-linked recessive benign haematological disorder characterised by bleeding manifestations and coagulation abnormalities. Haemophilia-A (HA) is more common form of the disease and is associated with deficiency of factor VIII (FVIII). Here we present an interesting case of a 16-year-old boy from the low socioeconomic strata, who was diagnosed to have severe HA (FVIII activity $<1 \%$ ) in early childhood.

By early pubertal age, he developed osteoarthropathy of left elbow joint secondary to recurrent episodes of haemarthrosis and due to nonaffordability of FVIII therapy. This time, he presented with acute onset, unprovoked, painful, gradually progressive swelling over left side of the back. On examination, there was a large, subcutaneous, mildly tender, non-pitting, non-pulsatile, diffuse swelling over the left side of the back extending

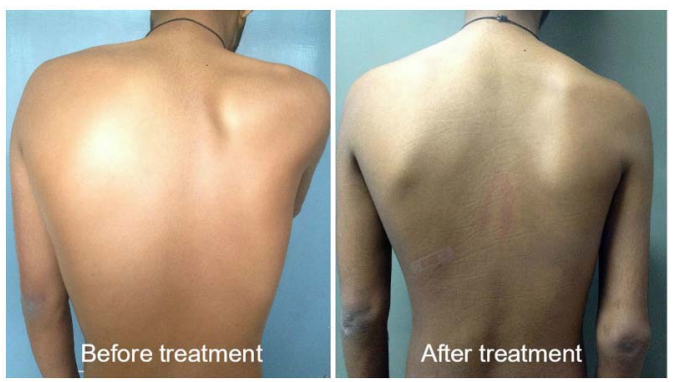

Figure 1 Clinical examination showing large subcutaneous haematoma in the back in the initial period followed by complete resolution of the swelling after fresh frozen plasma transfusion.
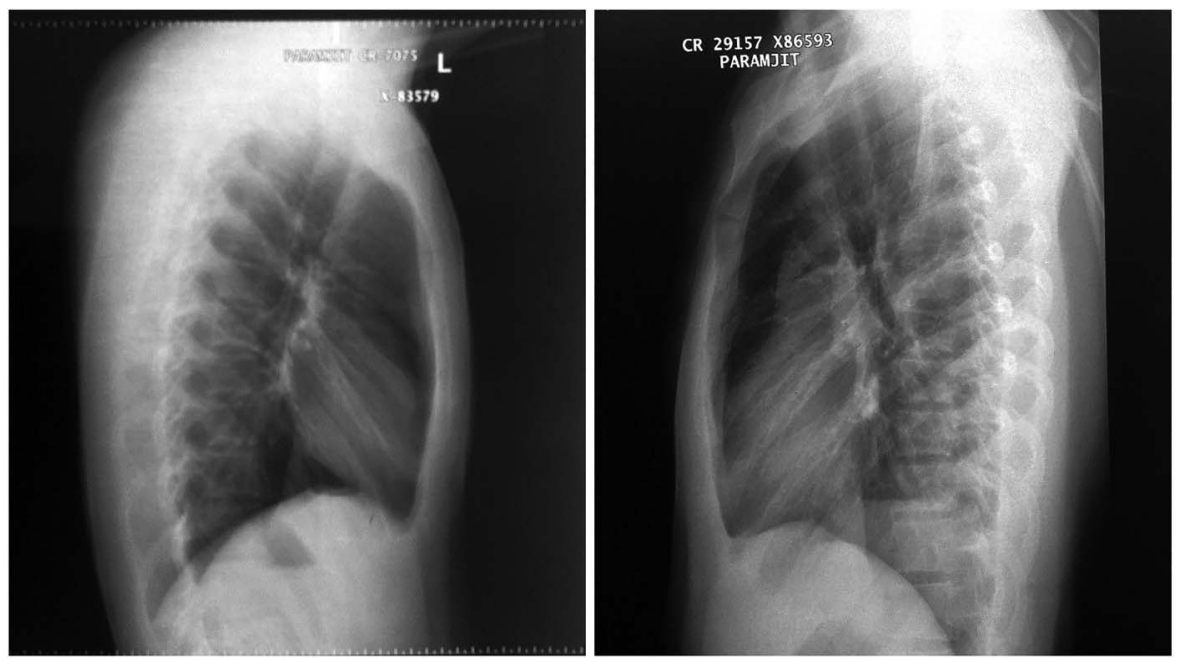

Figure 2 Chest X-ray (lateral view) showing soft tissue haematoma in the back, followed by resolution of soft tissue collection after fresh frozen plasma transfusion. inferiorly up to the inferior angle of left scapula of $\sim 16 \mathrm{~cm} \times 12 \mathrm{~cm}$ (figure 1).

The standard treatment in such case would be weight-based FVIII concentrate. ${ }^{1}$ However, this treatment is very costly and in a resource-limited country, it is usually not feasible or realistic in many cases. Cryoprecipitate and fresh frozen plasma (FFP) are acceptable ways of supplementing FVIII. However, the use of FFP is limited by the volume overload, and it can increase FVIII to a maximum concentration of $15-20 \%$ only. $^{2}{ }^{3}$

As the patient could not afford FVIII concentrate and bleeding was located in a non-vital region, patient was managed with FFP as a cheap, easily available alternative therapy. He was transfused FFP at the rate of $15 \mathrm{~mL} / \mathrm{kg} /$ day for 7 days. Excellent response was noted in the form of significant reduction in the swelling and pain, along with improvement in joint mobility in 7 days (figures 1 and 2).

\section{Learning points}

- In a resource-constrained situation, management of a non-fatal bleed in haemophilia should be promptly started with alternative therapy, in order to decrease the debility of haemophiliacs.

- Fresh frozen plasma (FFP) is an effective alternative therapy for non-fatal haematoma in haemophilia-A.

- Fluid overload and minimal recovery of factor VIII level are major limitations for FFP transfusion. 
Competing interests None declared.

Patient consent Obtained.

Provenance and peer review Not commissioned; externally peer reviewed.

\section{REFERENCES}

1 Sørensen B, Benson GM, Bladen M, et al. Management of muscle haematomas in patients with severe haemophilia in an evidence-poor world. Haemophilia 2012;18:598-606.
2 Nascimento B, Callum J, Rubenfeld G, et al. Clinical review: fresh frozen plasma in massive bleedings - more questions than answers. Crit Care 2010;14:202.

3 Holland LL, Brooks JP. Toward rational fresh frozen plasma transfusion: the effect of plasma transfusion on coagulation test results. Am J Clin Pathol 2006;126: 133-9.

Copyright 2016 BMJ Publishing Group. All rights reserved. For permission to reuse any of this content visit http://group.bmj.com/group/rights-licensing/permissions.

BMJ Case Report Fellows may re-use this article for personal use and teaching without any further permission.

Become a Fellow of BMJ Case Reports today and you can:

- Submit as many cases as you like

- Enjoy fast sympathetic peer review and rapid publication of accepted articles

- Access all the published articles

- Re-use any of the published material for personal use and teaching without further permission

For information on Institutional Fellowships contact consortiasales@bmjgroup.com

Visit casereports.bmj.com for more articles like this and to become a Fellow 